density (164 people per $\mathrm{km}^{2}$; Mittermeier et al., 2011, in Zachos \& Habel, Biodiversity Hotspots, pp. 3-22), and overexploitation of natural resources is putting plant diversity and related ecosystem services under threat. A significant step for the effective conservation of the native flora of the Caribbean Islands was taken on 7 February 2017, when the new seed bank of the Jardín Botánico Nacional 'Dr. Rafael Ma. Moscoso' of Santo Domingo in the Dominican Republic was officially launched. This seed bank is the result of a long-term collaboration between the Jardín Botánico Nacional and the Royal Botanic Gardens, Kew, and is regulated under an access and benefit-sharing agreement. This started in 2007 within the Millennium Seed Bank Partnership and is continuing through The Global Tree Seed Bank Project, Saving the Threatened Forest of Hispaniola, funded by the Garfield Weston Foundation. This collaboration has already led to the duplication and germination testing of 328 seed lots (194 species) at Kew's Millennium Seed Bank in the UK. In addition, the technical and scientific support of Kew staff during the last 10 years contributed to the design of the Jardín Botánico Nacional seed bank in line with international standards for long-term conservation in gene banks.

The opening of this seed bank not only strengthens the capacity of the Jardín Botánico Nacional to conserve the seeds of the flora of Hispaniola in-country, contributing towards Target 8 of the Global Strategy for Plant Conservation (At least $75 \%$ of threatened plant species in ex situ collections, preferably in the country of origin, and at least $20 \%$ available for recovery and restoration programmes), but will also facilitate research on seed biology of tropical tree species, for which information on seed storage behaviour is currently lacking. In particular, the project is screening the seed storage behaviour of endemic, threatened and useful tree species of the island. The results of this study will facilitate the appropriate seed management of native trees in reforestation programmes on the island.

The Jardín Botánico Nacional seed bank will be a platform for the conservation of the native flora of the Dominican Republic, and for supporting reforestation programmes both there and in neighbouring Haiti. With an emphasis on useful trees, the seed conservation programme will also contribute to the livelihoods of the island and in particular to UN Sustainable Development Goal 2 (Zero Hunger) by maintaining the genetic diversity of seeds, and goal 15 (Life on Land). In addition, the sustainable use of the stored seeds of native species in reforestation programmes will contribute to goal 1 (No Poverty), Goal 3 (Good Health and Well-being) and Goal 13 (Climate Action).

These new facilities and scientific collaboration between the Jardín Botánico Nacional and the Royal Botanic Gardens, Kew, working together with existing governmental and research institutions in the Caribbean Islands, will play a pivotal role in supporting reforestation and livelihoods in the region.
Efisio Mattana, Keith R. Manger, Michael J. Way and Tiziana Ulian Royal Botanic Gardens, Kew, Ardingly, West Sussex, UK. E-mail e.mattana@kew.org

Ricardo Garcia, Wilkin Encarnacion, Teodoro Clase, Brigido Peguero and Francisco Jimenez Jardín Botánico Nacional 'Dr. Rafael Ma. Moscoso', Santo Domingo, Dominican Republic

\section{First photographs of chimpanzees in the Omo Forest Reserve, Nigeria}

An opportunistic camera-trap survey has captured the first evidence in over 10 years that chimpanzees Pan troglodytes survive in the Omo Forest Reserve, Ogun State, Nigeria. Two photographs taken at separate locations on 2 September 2016 are the first photographic evidence of this species in Omo and the first confirmed records since nests and vocalizations were reported in June 2006 (Greengrass, 2006, A Survey of Chimpanzees in South-West Nigeria, nigeria.wcs.org/wildlife/nigeria-cameroon-chimp. aspx). Fieldwork by the Omo-Shasha-Oluwa Forest Initiative had already established that local communities knew of the continued existence of chimpanzees, and a sighting of three individuals had been reported in July 2015. Chimpanzees in south-west Nigeria are included in the Regional Action Plan for the Conservation of the NigeriaCameroon Chimpanzee P. troglodytes ellioti, although their taxonomic status has yet to be determined genetically. Other globally threatened vertebrates recently recorded in Omo include African elephants Loxodonta africana (assumed to be the forest taxon cyclotis), red-capped mangabey Cercocebus torquatus, Nigerian white-throated guenon Cercopithecus erythrogaster pococki, white-bellied pangolin Phataginus tricuspis, grey parrot Psittacus erithacus, yellow-casqued hornbill Ceratogymna elata and African dwarf crocodile Osteolaemus tetraspis.

The Omo Forest Reserve, together with the contiguous Shasha and Oluwa Forest Reserves, in Osun and Ondo States, respectively, constitutes one of the largest remaining forested areas is south-west Nigeria, a region largely neglected by international conservation efforts despite the presence of threatened species. Located in the transition zone between the Upper and Gulf of Guinea forest biomes, this area was formerly part of a large swath of forest linking the dry forest of the Dahomey Gap (Togo and Benin) to the Niger Delta and stretching up to $400 \mathrm{~km}$ inland from the coast.

The remaining patches of natural forest are largely within state forest reserves established by the British colonial government in the early 2oth century for timber production and watershed protection. In some cases, communities living within the boundaries of forest reserves were permitted to remain, within legal enclaves. There was also high 
migration to certain reserves in the 1970 s associated with establishment of exotic timber plantations on land cleared of natural forest. A small area in the Omo Forest Reserve $\left(4.6 \mathrm{~km}^{2}\right)$ was designated a Strict Nature Reserve in 1946 and parts of the Reserve were declared a UNESCO Man and the Biosphere Reserve in 1977. Despite these designations, Omo and the adjacent forest reserves of south-west Nigeria remain subject to uncontrolled logging, clearance for farms and plantations, and hunting of wildlife.

All the aforementioned species are threatened by the loss of habitat as forests are cleared and fragmented by farming. Moreover, even where forest remains, it continues to be degraded by the removal of timber or clearance of understorey, vegetation for planting shade-tolerant crops, such as cocoa. Hunting, most commonly for bushmeat but also for the commercial trade in illegal wildlife products and in retaliation for crop-raiding, is also a major threat.

The concept of legally protecting and coordinating the management of the remaining natural forest within the Omo, Shasha and Oluwa Forest Reserves was proposed in a management plan in 2011 by the Omo-Shasha-Oluwa Forest Initiative. The Initiative comprises the Nigerian Conservation Foundation, Whitley Wildlife Conservation Trust, and Forestry Research Institute of Nigeria in partnership with the state governments of Ogun, Osun and Ondo and with the support of the A.P. Leventis Ornithological Research Institute, Nigeria, and Environmental Resource Management, UK.

The management plan developed by the Initiative identified specific logging compartments for designation as a wildlife sanctuary in which further logging, farming and hunting would be prohibited. Progress towards this goal was reinvigorated with the first meeting of the Omo-Shasha-Oluwa Forest Initiative steering committee in August 2016 and a subsequent meeting with state government representatives in October 2016, in Lagos. This formal coordination of conservation efforts and engagement with state governments, together with recent species records, including the camera-trap photographs of chimpanzees in Omo, provide hope that it is not too late to protect these important forests and their distinctive wildlife.

Olabode Emmanuel, titus Onyenen, Stella Egbe and Clifford Omonu Omo-Shasha-Oluwa Forest Initiative, Omo Forest Reserve, Nigeria, and Nigerian Conservation Foundation, Lekki Conservation Centre, Lagos, Nigeria

ANDREW E. BOWKETT and LOUISE FRANCIS Whitley Wildlife Conservation Trust, Paignton, UK

E-mail Andrew.bowkett@paigntonzoo.org.uk

Tunde MoRakinyo Environmental Resources Management, London, UK
Philip HaLl The A.P. Leventis Ornithological Research Institute, Jos, Nigeria

ADESHOLA ADEPOJU Forestry Research Institute of Nigeria, Ibadan, Nigeria

ONOJA JosePh and ADENIYI KaRUNWI Nigerian Conservation Foundation, Lekki Conservation Centre, Lagos, Nigeria

\section{A new programme for conservation of Plant Species with Extremely Small Populations in south-west China}

Plant Species with Extremely Small Populations, a conservation concept developed in China in 2005, are characterized by small remaining populations (lower than the minimum viable population), a restricted habitat, a high risk of extinction, and exposure to a high level of disturbance. A species with fewer than 5,000 mature individuals in the wild and fewer than 500 in each isolated population (except when only one population is known) qualifies for designation under Plant Species with Extremely Small Populations. The identification of a high level of disturbance and irreversible habitat destruction distinguishes Plant Species with Extremely Small Populations from naturally rare species. In 2012 China's State Forestry Administration issued the national Implementation Plan for Rescuing and Conserving China's Plant Species with Extremely Small Populations, listing 120 plant species. Province-level conservation plans and lists followed.

To promote the conservation of Plant Species with Extremely Small Populations, the Ministry of Science and Technology granted funding for a National Key Programme: Survey and Germplasm Conservation of Plant Species with Extremely Small Populations in South-west China (grant number: 2017FY100100). The programme started in February 2017 and will last for 5 years, with funding of RMB 24.26 million (USD 3.52 million). Kunming Institute of Botany, of the Chinese Academy of Sciences, is leading this programme, with the participation of 13 other organizations.

The programme will include extensive field surveys of 231 species, including national- and province-level lists of Plant Species with Extremely Small Populations, in south-west China, where the geographical features are diverse and mountainous. The Mountains of South-west China biodiversity hotspot lies within this region. The survey area comprises 1.46 million $\mathrm{km}^{2}$, and includes Yunnan, Guizhou, Sichuan, Chongqing, west Guangxi, and southeast Xizang Provinces. Although this is only $15 \%$ of China's land area, it includes more than $60 \%$ of China's flora and threatened plant species.

One requirement of the programme is that at least 70 species will be propagated and conserved ex situ in botanical 